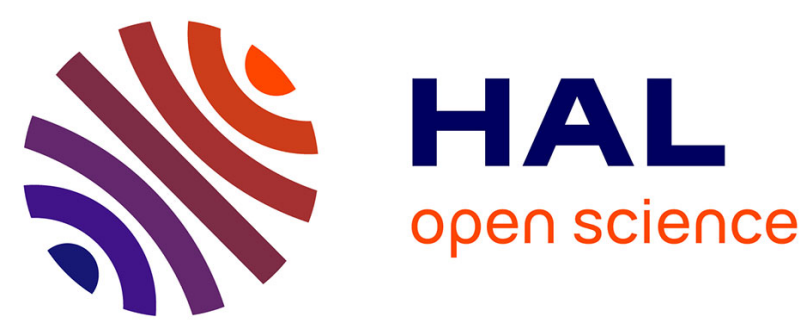

\title{
Tree species identification on large-scale aerial photographs in a tropical rain forest, French Guiana-application for management and conservation
}

Valérie Trichon, Marie-Pierre Julien

\section{- To cite this version:}

Valérie Trichon, Marie-Pierre Julien. Tree species identification on large-scale aerial photographs in a tropical rain forest, French Guiana-application for management and conservation. Forest Ecology and Management, 2006, 225 (1-3), pp.51-61. 10.1016/j.foreco.2005.12.046 . hal-01360743

HAL Id: hal-01360743

https://hal-univ-tlse2.archives-ouvertes.fr/hal-01360743

Submitted on 6 Sep 2016

HAL is a multi-disciplinary open access archive for the deposit and dissemination of scientific research documents, whether they are published or not. The documents may come from teaching and research institutions in France or abroad, or from public or private research centers.
L'archive ouverte pluridisciplinaire HAL, est destinée au dépôt et à la diffusion de documents scientifiques de niveau recherche, publiés ou non, émanant des établissements d'enseignement et de recherche français ou étrangers, des laboratoires publics ou privés. 


\title{
Tree species identification on large-scale aerial photographs in a tropical rain forest, French Guiana—application for management and conservation
}

\author{
Trichon Valérie*, Julien Marie-Pierre ${ }^{1}$ \\ LADYBIO (CNRS and Université Paul Sabatier), 29 rue Jeanne Marvig, BP 4009, 31055 Toulouse cedex 4, France
}

\begin{abstract}
Management and conservation planning of any ecosystem requires knowledge of species composition. This is a real challenge in tropical rain forests that are characterised by very high species richness and canopy access limitations. The possibility of approaching trees from remote sensing on large-scale aerial photographs, takes on its full significance in this context. Results of tree species identification by photo-interpretation in a French Guianan forest canopy are discussed, as well as an overview of the part of the forest accessible from the photographs. Two sets of aerial photographs were used. One set (1:3700 colour slides) covers 15 ha of primary forest, divided into a training set (TS, 5 ha) and a validation set (VS 1: $10 \mathrm{ha}$ ). Another validation set, taken in different conditions of acquisition, scale and season, is available for an adjacent area (VS 2: 6.5 ha). Aerial photographs captured a quarter of the tree community $(\mathrm{dbh} \geq 10 \mathrm{~cm}$ ) on average, and about $45 \%$ of the SGS (Species or Group of Species) on the training set. The crown appearance of 12 major canopy SGS, including commercial species and species of ecological interest, had been described in a previous work on the same training set. Following these descriptions, two photo-interpreters separately identified 309 tree crowns overall on VS 1, with a good agreement in their respective judgements. After their interpretations were checked in the field, the overall average identification success was high (87\%) but the results varied according to the SGS. The results on VS 2 showed that some species displayed major seasonal and scale variations and were hardly recognized, whereas some others could be identified without modifying the learning process. The results are encouraging and this work will be extended as the identification of tropical rain forest trees from remote sensing has many applications, ranging from fundamental ecological knowledge of canopy species to the management and conservation of such highly diverse and hardly inventoried ecosystems.
\end{abstract}

Keywords: Tree species identification; Tropical rain forest; Aerial photographs; Forest canopy; Photo-interpretation; French Guiana

\section{Introduction}

As tropical rain forests disappear at alarming rates, we need to develop novel techniques to ensure the ongoing conservation of this ecosystem (Mittermeier et al., 1998; Hill, 2003). Management or conservation decisions for tropical rainforests, as in any natural ecosystem, often result from a multitude of biological criteria (Margules, 2000). Many of them are related to the assessment of biodiversity and imply the knowledge of

\footnotetext{
* Corresponding author at: LAboratoire DYnamique de la BIOdiversité, Université Paul Sabatier, Bat. 4R3, 31052 Toulouse cedex 9, France.

Tel.: +33 5615585 47; fax: +33561556728.

E-mail address: trichon@cict.fr (T. Valérie).

${ }^{1}$ Present address: DYNAFOR, B.P. 27, 31326 Castanet Tolosan cedex, France
}

species composition since some species may have a particular importance (Gentry, 1992; Myers et al., 2000; Hobhom, 2003). This is a major problem in tropical rain forests, which are characterised by their high density and their high species richness. The great trees in particular, which form the skeletal structure of these forests, develop their crowns several dozen metres high, out of sight from the ground, hidden by intermediate tree foliage.

The possibility of approaching trees from remote sensing platforms, rather than from ground-level takes on its full significance in this context, and various tools come into their own in an attempt to meet this need (see Sutton, 2001, for a review of canopy access techniques). New very high resolution remote sensing data (pixel size around $1 \mathrm{~m}$ ) allow one to locate crowns in the rain forest canopy (Read et al., 2003; Clark et al., 2004) but are still not sensitive enough for 
species identification. Likewise, a method of identification of canopy trees through large-scale aerial photographs, without having the ambition to replace sample collection, would enable foresters, botanists and ecologists to survey larger surface areas than permitted by analysis from the ground. This approach may also allow areas to which access is otherwise particularly difficult to be surveyed. Such a method could be devoted to the identification of particular species of interest in a conservation or management framework: endemic species, commercially valuable species, patrimonial species, indicators of soil conditions, of disturbance level, of dynamic status.

Studies regarding the feasibility of tropical forest species identification by aerial viewing have mainly been carried out for the identification of one or two given species (Nyyssönen, 1962 for a review; Clément and Guellec, 1974; Vooren and Offermans, 1985; Herwitz et al., 1998). Published results dealing with the identification of a range of tropical forest species in natural stands are rare: Sayn-Wittgenstein et al. (1978) in Surinam, Myers and Benson (1981) in Australia. The results obtained by Sayn-Wittgenstein et al. (1978) are encouraging but they conclude that their identification criteria require further work. In comparison, the approach of Myers and Benson (1981) works. It therefore seemed of interest for us to attempt a similar study on a forest in French Guiana, where a great scientific effort is developed in forest studies, including methodology for the assessment of forest characteristics.

In a previous publication, Trichon (2001) drew up a list of 12 Guianese forest trees likely to be identifiable by aerial viewing. Each species (or group of species) was described according to criteria redefined based on the earlier works on the subject (Sayn-Wittgenstein et al., 1978; Myers, 1982). Here, we present results of the identification success of these species by photo-interpretation, in various conditions of photograph acquisition, scale or season. Since forest canopy is the only emergent portion of the whole forest, we first give an overview of the part of the forest accessible through large-scale aerial photographs.

\section{Materials and methods}

\subsection{Study area}

The study was undertaken in French Guiana, on the Paracou Experimental Station $\left(5^{\circ} 15^{\prime} \mathrm{N} ; 52^{\circ} 56 \mathrm{~W}\right)$ operated by the CIRAD-forêt ${ }^{1}$ since 1984 (Gourlet-Fleury et al., 2004). Paracou is located $15 \mathrm{~km}$ from the Atlantic coast, $50 \mathrm{~km}$ North-West of Kourou (Fig. 1). The climate is equatorial with a mean annual temperature of $26^{\circ} \mathrm{C}$ and a mean annual rainfall of around $3000 \mathrm{~mm}$. Rainfall is bimodal with peaks during the long wet season from April to July and the short rainy season in December-January, separated by a long dry season from August to November and a short dry season in FebruaryMarch. Most of Paracou Experimental Station occurs on a

\footnotetext{
${ }^{1}$ CIRAD-forêt: Forest department of the International Research Centre for Agronomy and the Development, TA 10/D, 34398 Montpellier cedex 5, France.
}

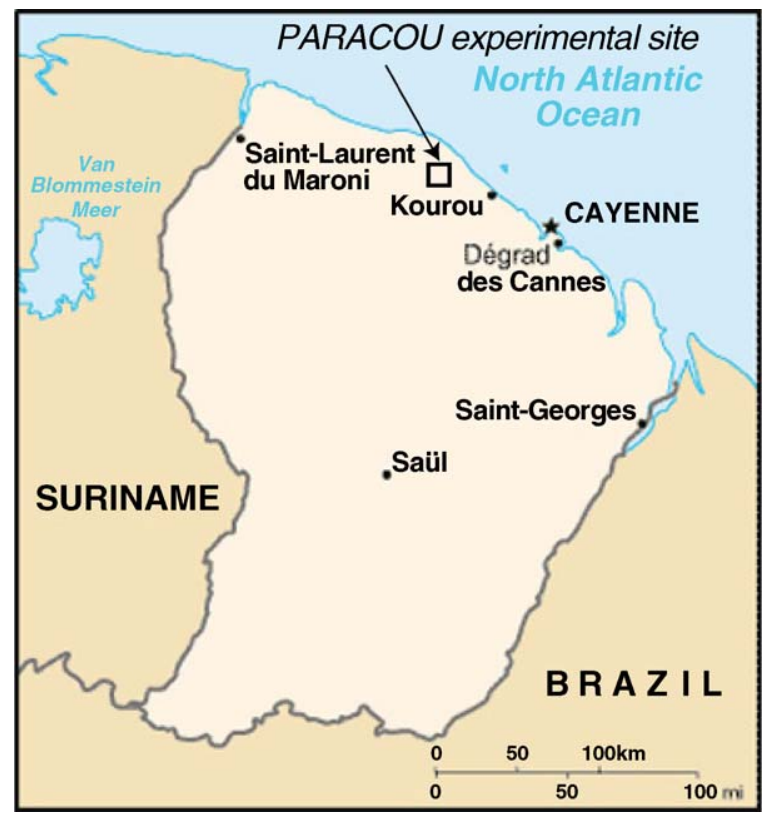

Fig. 1. Location of Paracou experimental site, French Guiana.

globally homogeneous formation characterised by schists and sandstones, locally crossed by veins of pegmatite, aplite and quartz. The relief consists of small hills (5-45 m above sea level) separated by narrow sandy waterbeds. Paracou, like most of French Guiana, is covered by lowland "terra firme" rain forest with a tree species richness above 140 trees/ha for trees having a diameter at breast height $(\mathrm{dbh})$ above $10 \mathrm{~cm}$ (Sabatier and Prévost, 1990). Over 119 ha (16 plots), trees above $10 \mathrm{~cm} \mathrm{dbh}$ are labelled, inventoried and monitored. Their location, diameter and botanical identification are recorded in a database (Cirad-Forêt database of Paracou). Botanical identifications are limited to 200 SGS (Species or Group of Species), some of them corresponding to one single species, some other to two or more species. Our work was conducted in two plots of undisturbed rain forest among the 16 plots that are monitored at Paracou: Plot P16 (25 ha) and plot P11 (6.25 ha).

\subsection{Aerial photographs}

Photographs were taken along parallel transects, enabling stereoscopic views between photo-pairs. We surveyed the P16 plot in October 1996 from a hot-air airship during the "Opération Guyane 96" scientific mission (Trichon et al., 1998). Flights were done on 3 successive days between 6.30 and $7.30 \mathrm{am}$. We used a FM2 Nikon ${ }^{\circledR}$ camera with a $35 \mathrm{~mm}$ lens loaded with colour slides (Fuji ${ }^{\circledR}$ Sensia, 400 ASA). The average scale of the slides is 1:3700.

Photographs over the P11 plot were taken in July 1997 from a helicopter, at three altitudes (Chareyre, 1998). The scales of the slides were approximately 1:1500, 1:3000 and 1:8000, respectively. The camera was loaded with 100 ASA colour slides (Fuji ${ }^{\circledR}$ Sensia) due to the greatest luminosity during the flights (middle and late morning). Photo 1 displays a view of the forest canopy at each scale. 

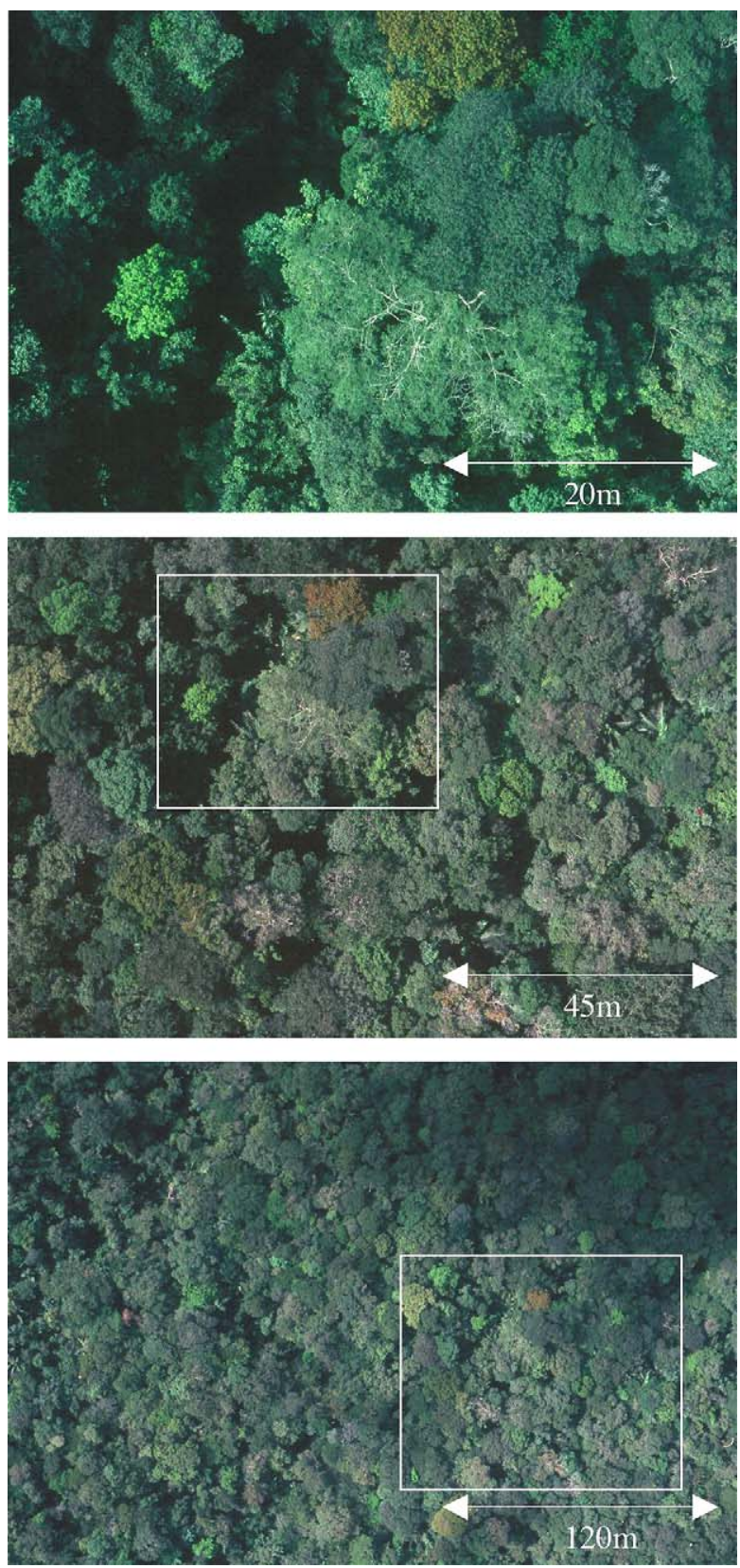

Photo 1. View of forest canopy at three scales on plot P11, Paracou. Original scales of the slides, from the bottom up, are: $1: 8000 ; 1: 3000 ; 1: 1500$. Photographs, D. Guillemyn.

In each plot, we used mylar balloons filled with helium to serve as spatial landmarks, both during the flight and for further mapping of the canopy. Digital photomosaics were built and inserted in the Paracou GIS. Paper photomosaics were also produced to help locating during field work.

\subsection{Training set and the species or group of species studied}

The photographs cover about 15 ha of the P16 plot. A 5 ha area served as a training set (TS) for species description (Fig. 2). The crowns depicted on the photographs were recognized from the ground mainly by referring to their shape,

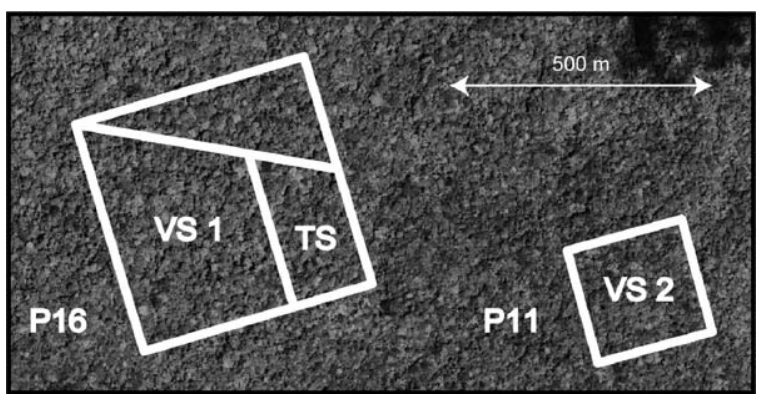

Fig. 2. Design of photographic training set (TS) and validation sets (VS 1 and VS 2) for species identification over P16 and P11 plots, Paracou (plots are located on an IKONOS image, panchromatic band). Main characteristics of aerial photographic campains are: P16 (TS and VS 1): 1996, October, original scale: 1:3700, P11 (VS 2): 1997, July, original scales from 1:1500 to $1: 8000$.

size and location. Particular features such as palms, gaps, dead trees or very big trees that were easy to locate from the ground, were used as starting points or control points to ensure accurate connections between crowns on the photographs and trunks on the ground. We thus located 279 crowns on TS that represent 78 SGS (species or group of species). We then selected the 15 most abundant SGS for which at least 5 crowns were clearly visible on the photographs. Three of these categories showed a great variety of crown forms and were thus disregarded. A standard crown description was then established over the remaining 12 SGS, following the crown typology and the definition of the criteria quoted in Table 1 (Trichon, 2001). The crown key features for the 12 SGS observed on TS are given in Table 2, as well as the conformity of SGS names and botanical names. The expression SGS is used here since we referred to the identification given in the Paracou database and 3 of the 12 SGS studied do not correspond to a single species. Lebi koko is used for Licania cf. micrantha, but includes many Licania alba as well as other Chrysobalanaceae species. Maho cigare is for Couratari multiflora and other Couratari spp that may have different crown aspects. For example, the description given by Trichon (2001) fits the species Couratari multiflora, but not $C$. guianensis. Symphonia is for Symphonia globulifera and Symphonia sp.1 (Gourlet-Fleury et al., 2004, Annex 1 and 2). The other SGS have a good taxonomic concordance with one single species. Kimboto, which corresponds to Pradosia cochlearia, may be used for Pradosia ptychandra, but this species is a suppressed species unlikely to appear in the canopy (D. Sabatier, personal communication). In the rest of the article we will talk either about SGS or species when possible (when1 SGS corresponds to 1 single species). For commodity reasons we will more often use the SGS names to design the trees. However, the botanical names, when described, follow Boggan et al. (1997). Photo 2 shows the diversity of crown shapes in the canopy and displays an example of the SGS studied.

The SGS studied here present various interests. Angélique (Dicorynia guianensis), Wacapou (Vouacapoua Americana), Grignon (Ocotea rubra) are first category commercial species, and the most exploited species in French Guiana. Carapa 
Table 1

Crown typology and definition of each criteria used for tree species identification by photo-interpretation at Paracou, French Guiana (after Trichon, 2001)

\begin{tabular}{|c|c|c|}
\hline Classes of criteria & Sub-classes of criteria & Definition of criteria \\
\hline Crown size & $\begin{array}{l}\text { Small } \\
\text { Medium } \\
\text { Large }\end{array}$ & $\begin{array}{l}L<10 \mathrm{~m} \\
10 \mathrm{~m} \leq L \leq 15 \mathrm{~m} \text {-when } L \text { is the maximum width of the crown } \\
L>15 \mathrm{~m}\end{array}$ \\
\hline Crown status & $\begin{array}{l}\text { Dominant } \\
\text { Co-dominant } \\
\text { Supressed }\end{array}$ & $\begin{array}{l}\text { Above the mean canopy level, receiving side light } \\
\text { Part of the mean canopy level, crowded on the sides, receiving little side-light } \\
\text { Under the mean canopy level, lower than its neighbours, receiving no side-light }\end{array}$ \\
\hline Crown contour & $\begin{array}{l}\text { Round, elliptic, elongated } \\
\text { Regular lobate } \\
\text { Irregular }\end{array}$ & Contour has deep invaginations \\
\hline Crown architecture & $\begin{array}{l}\text { Flat } \\
\text { Rounded } \\
\text { Billowy } \\
\text { Tufted } \\
\text { Star-shaped } \\
\text { Layered } \\
\text { Segmented } \\
\text { Not segmented } \\
\text { Multiple } \\
\text { Single } \\
\text { Shallow } \\
\text { Deep }\end{array}$ & $\begin{array}{l}\text { More-or-less horizontal surface } \\
\text { Definite curvature of the crown surface, highest point in the middle } \\
\text { Surface rising and rolling in prominent waves reminiscent of a cumulus cloud } \\
\text { Individual branches (branching habit }>45^{\circ} \text { ) extending upward and outward } \\
\text { Branches or big componed leaves disposed in verticilles or in a spirale } \\
\text { Several separated segments } \\
\text { With individual crownlets separated by more or less prominent fissures } \\
\text { Not like above } \\
\text { Two or more large division within the crown, each component resembling an individual crown } \\
\text { Not like above, crown with a well-defined center, even in the case of discontinuous foliage } \\
\text { The foliage is concentrated to the top of the tree } \\
\text { The foliage is vertically distributed, from the top to approximately more than } 1 / 3 \text { of the total tree height }\end{array}$ \\
\hline Foliage cover & $\begin{array}{l}\text { Opaceous } \\
\text { Light } \\
\text { Continuous } \\
\text { Discontinuous }\end{array}$ & $\begin{array}{l}\text { Nothing is visible through the foliage } \\
\text { Branches or any other lower elements are distinguishable through the foliage } \\
\text { The foliage is regularly distributed within the crown } \\
\text { The foliage is concentrated in some parts of the crown, branches are visible in other parts }\end{array}$ \\
\hline Foliage texture & $\begin{array}{l}\text { Smooth } \\
\text { Smoky } \\
\text { Grainy } \\
\text { Granular } \\
\text { Loosely granular } \\
\text { Dotted }\end{array}$ & $\begin{array}{l}\text { No textural design is discernable at this scale of observation: } \\
\text { Opaceous and dense foliage with small compacted leaves } \\
\text { Opaceous or light foliage with leaves not compacted } \\
\text { Textural design is discernable: } \\
\text { Repetition of small particles giving a mottled appearance to the crown } \\
\text { Repetition of larger particles. These particles can be clusters of leaves or crownlets } \\
\text { The granular textural design is loosely repeated } \\
\text { The foliage is light and the leaves are separated, appearing like individual spot }\end{array}$ \\
\hline Colour & $\begin{array}{l}\text { Green, yellow, blue, grey, red, } \\
\text { Light, dark }\end{array}$ & Rough colour tones (can be combined together) \\
\hline Phenology & $\begin{array}{l}\text { Leaf shed } \\
\text { Flowering } \\
\text { Fruiting, flushing } \\
\text { Synchronism } \\
\text { Disynchronism }\end{array}$ & Of the phenological phenomenon at the species and/or at the crown levels \\
\hline
\end{tabular}

(Carapa procera), Goupi (Goupia glabra), Gonfolo rose (Qualea rosea) and Symphonia (Symphonia globulifera, Symphonia sp.1) are second category commercial species. Diaguidia (Sclerolobium melinonii), used on a large scale in neighbouring countries, can be exploited in French Guiana as a complementary species of first or second category species (Détienne et al., 1990). Carapa, Symphonia and Maho cigare are also largely used in whole tropical America by indigeneous people for traditional medicine (Grenand et al., 1987). Kimboto feeds several monkey species and rodents, whereas the Goupi's fruits, eaten and dispersed by the birds and monkeys appear all year round, at periods when other fruits are rare in the forest (Anonymous, 2001). Some of these species, as long-lived pioneers (Goupia glabra) indicate a local past disturbance.

\subsection{Validation sets and process of tree species identification by photo-interpretation}

Two photo-interpreters separately attempted to recognize the 12 SGS on the first validation set (VS 1: 10 ha) consisting of the remaining set of photos over the P16 plot (Fig. 2). They did it first with the normal view, and second with the stereoscopic view, which is used for assessing the criteria of crown status or crown architecture (Table 1). The identifications were classified according to the degree of certainty expressed by the interpreter: hesitant or definite. Afterwards, the photointerpreters worked jointly on the second validation set (VS 2: $6.25 \mathrm{ha}$ ) consisting of the photographs taken over the P11 plot (Fig. 2). This allowed us to assess the robustness of our method under various conditions of acquisition. The two validation 
Table 2

Crown key features for the 12 SGS (species or group of species) observed on a training set area (part of P16 plot), Paracou experimental station, French Guiana (after Trichon, 2001)

SGS (species or group of species) Crown key features

botanical name, family

\section{Angélique \\ Dicorynia guianensis, Caesalpiniaceae}

Carapa

Carapa procera, Meliaceae

Diaguidia

Sclerolobium melinonii, Caesalpiniaceae

Gonfolo gris

Ruizterania albiflora, Vochysiaceae

Gonfolo rose

Qualea rosea, Vochysiaceae

Goupi

Goupia glabra, Celastraceae

Grignon

Ocotea rubra, Lauraceae

Kimboto

Pradosia cochlearia, Sapotaceae

Lebi koko

Licania spp., Chrysobalanaceae

Maho cigare

Couratari multiflora, C. spp., Lecythidaceae

Symphonia

Symphonia globulifera, S. sp.1, Clusiaceae

Wacapou

Vouacapoua americana, Caesalpiniaceae
Large, co-dominant to emergent, deep, rounded, opaceous to light foliage, dark to greyish green, grainy to granular texture

Small, multiple crown, tufted branches and star-shaped crownlets

Medium, co-dominant, round, layered, opaceous and continuous yellowish green foliage, grainy texture

Large, emergent, round, opaceous and continuous light green foliage, granular texture (crownlets)

Large, codominant to emergent, cauliflower-like crown, opaceous and continuous dark green foliage, smooth texture

Large, co-dominant, tufted, opaceous to light foliage bluish green to grey, smoky texture

Large, co-dominant to emergent, deep and billowy crown, discontinuous light green foliage, loosely granular texture

Large, emergent, layered, opaceous to light foliage, discontinuous, grey-green to orange, smoky texture

Small and suppressed, mottled colour green/orange, grainy texture

Medium, emergent, light and discontinuous foliage, light green to yellow, dotted texture

Small, suppressed to emergent, single star-shaped crown

Medium, co-dominant to suppressed, rounded, opaceous and continuous bluish-green foliage, granular texture
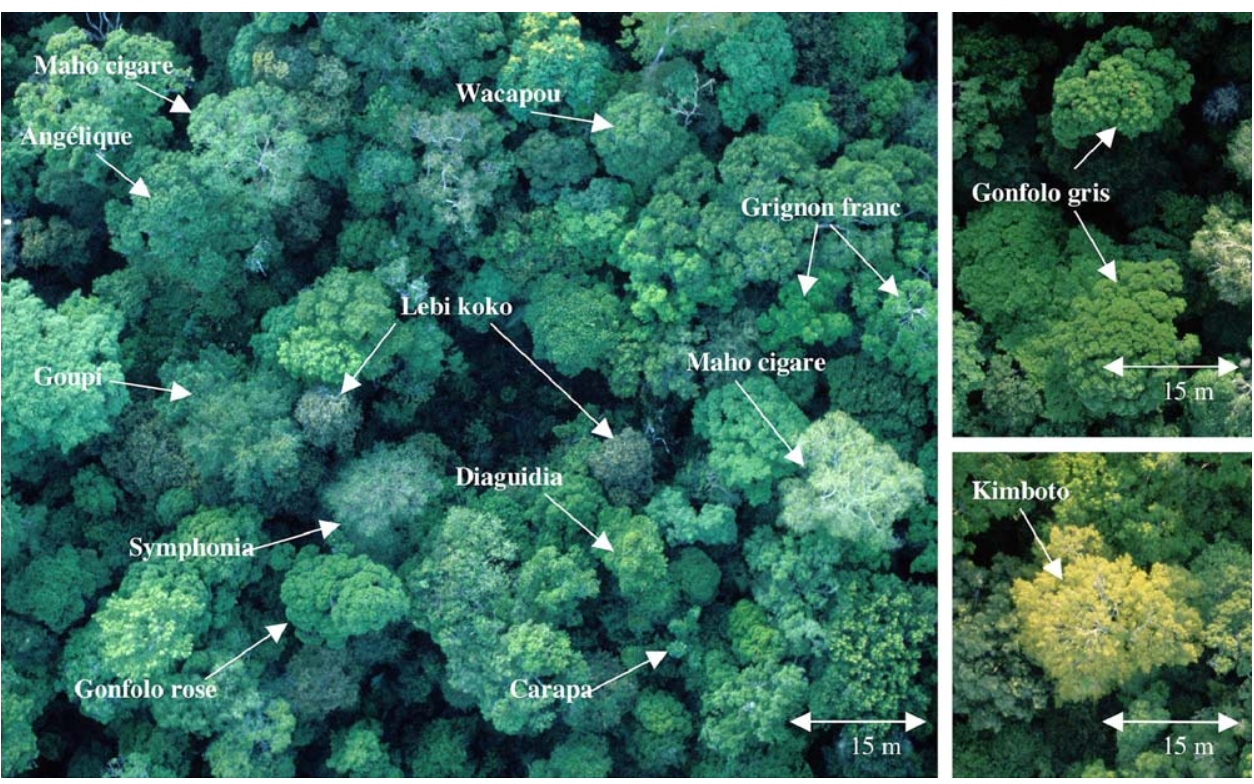

Photo 2. Aerial photographs of P16 Plot (Paracou, French Guiana) displaying the species studied. Photographs, D. Guillemyn. 
sets VS 1 and VS 2 differ first in season (middle of dry season against late of rainy season). This may modify the characteristics of the crowns regarding phenological processes such as flowering, leaf flushing, leaf falling. There is also a difference in luminosity between VS 1 and VS 2 (early morning against middle and late morning) and in film sensitivity (400-100 ASA) that may influence the colour of the crowns on the photographs. Lastly, we attempted to assess if a SGS that was described and recognize at a given scale (1:3700 on TS and VS 1) could be recognized at other scales (1:1500 to $1: 8000$ on VS 2).

Field trips subsequently enabled these interpretations to be checked by retrieving from the ground the trees identified on the photographs. We followed the same method used for the training set (photomosaics, easy control points, GIS).

\section{Results}

\subsection{Part of the forest cover accessible through aerial photographs}

The results given in Table 3 are based on VS 2 and a part of TS (4 ha).

\subsubsection{Canopy tree density}

We calculated the proportion of trees clearly visible in the canopy (where the crown was entirely in the canopy, or partially present but visible enough to be recognized) compared to the total number of trees $(\mathrm{dbh} \geq 10 \mathrm{~cm})$. We obtain $24.5 \%$ over TS (134 crowns/ha) and $20.8 \%$ over VS 2 (143 crowns/ha, Table 3 ). This percentage varies according to forest structure (e.g. total tree density, relative percentage of small trees not visible in the canopy) and to the species present in the canopy (e.g. relative percentage of spread-out crowns and of emergent trees having wide crowns, thus masking the other canopy trees). None of the crowns located in the canopy belong to trunks with a dbh under $20 \mathrm{~cm}$. These results encompass some bias because it was sometimes difficult to distinguish between two crowns of the same species if they

Table 3

Part of the forest cover accessible through large-scale aerial photographs, measured on TS (part of P16 plot) and VS 2 (P11 plot), Paracou experimental station

\begin{tabular}{lcc}
\hline & $\begin{array}{l}\text { Training set } \\
(4 \text { ha) }\end{array}$ & $\begin{array}{l}\text { Validation set 2 } \\
(6.25 \text { ha })\end{array}$ \\
\hline Database information & & \\
Total number of trees, dbh $\geq 10 \mathrm{~cm}$ & 2188 & 4300 \\
SGS (species or group of species) & 130 & 156 \\
Photo-interpretation (1:3700 to 1:3000) & & \\
$\quad$ Delimited crowns & 535 & 895 \\
Mean canopy tree density (crowns/ha) & 134 & 143 \\
\% of trees in canopy & 24.5 & 20.8 \\
Ground check & & \\
Crown-trunk connexion & 178 & 454 \\
$\%$ among total trees & 8.1 & 10.6 \\
$\%$ of SGC observed in canopy & 44.6 & 48.8 \\
\hline
\end{tabular}

were clumped (this may happen for gregarious species like Angélique). Alternatively, multiple crowns (Table 1) like those of some Gonfolo rose could lead to an overestimation of the tree density. In most cases however, we had no difficulty delineating the crowns and we consider that our percentages give a good estimation of the part of the trees that are remotely visible at our sites.

\subsubsection{Canopy tree species diversity}

Assessment of species diversity of trees visible in the canopy, unlike for tree density, relies on the botanical identification of the trees observed. It also implies that the crowns have been localised, that means that the connection from crowns (on the photographs) to trunks (at ground-level) has been made. In a reasonable time of field work (e.g. 7 days, 2 people over the 4 ha of TS) we localised the crowns of 8.1 and $10.6 \%$ of the total trees on TS and VS 2, respectively (Table 3 ). These crowns represent almost 45 and $49 \%$ of the SGS listed over the respective plots (4 ha and $6.25 \mathrm{ha}$ ). Allowing for accurate identification of species instead of the SGS names would modulate this percentage but not to any significant degree.

\subsection{Results of tree species identification by photo- interpretation}

\subsubsection{Agreement between photo-interpreters}

On VS 1, the two photo-interpreters separately identified a very similar number of crowns: 158 and 151, respectively, but with a difference in the use of their hesitant judgements: 10.5 and $20.8 \%$ of hesitation in their identification, respectively. The more "hesitant" interpreter made less error in her definite identifications: $88 \%$ of correct identifications as opposed to $86 \%$ for the other interpreter. However, the former made more errors overall: $83.4 \%$ success as opposed to $84.8 \%$.

Overall, 309 crown identifications $(158+151)$ were made during this work. The overall agreement between the photointerpreters is $78.3 \%$ (121 identical identifications, either correct or wrong). The agreement of correct identification is $73.8 \%$ (114 identical and correct identifications). This generally acceptable agreement between the photo-interpreters indicates that the method is reproducible from one person to another.

\subsubsection{Stereoscopic improvement}

Adding the stereoscopic information on VS 1 only slightly improved the identification success of both photo-interpreters in this study. After 309 identifications, only two confusion errors were corrected with the stereoscopy and 11 hesitant but correct identifications were confirmed to definite ones. This may be an important result in the prospect of fast tree inventories by photo-interpretation. However, the stereoscopic information may be useful for species other than those studied here.

\subsubsection{Identification success}

We have chosen to give here the results of both photointerpreters by compiling their observations in a single table (Table 4), following Myers and Benson's (1981) approach. SGS are listed following the decreasing number of correct 
Identification success by both photo-interpreters, definite judgements only

\begin{tabular}{|c|c|c|c|c|c|c|c|c|c|c|}
\hline & \multicolumn{10}{|c|}{ Photographic set } \\
\hline & \multirow{3}{*}{$\begin{array}{l}\text { Training set } \\
1: 3700^{\mathrm{a}} \\
\text { Reference } \\
\text { trees }\end{array}$} & \multirow{2}{*}{\multicolumn{3}{|c|}{$\begin{array}{l}\text { Validation set } 1 \\
1: 3700^{\mathrm{a}}\end{array}$}} & \multicolumn{6}{|c|}{ Validation set 2} \\
\hline & & & & & \multicolumn{2}{|l|}{$1: 1500^{\mathrm{a}}$} & \multicolumn{2}{|l|}{$1: 3000^{\mathrm{a}}$} & \multicolumn{2}{|l|}{$1: 8000^{\mathrm{a}}$} \\
\hline & & $\begin{array}{l}\text { Judgements } \\
(\times 2)^{\mathrm{b}}\end{array}$ & $\begin{array}{l}\text { Average } \\
\% \text { success }\end{array}$ & $\begin{array}{l}\text { Best \% } \\
\text { success (trees) }\end{array}$ & $\begin{array}{l}\text { Judgements } \\
(\times 1)^{\mathrm{c}}\end{array}$ & $\%$ success & $\begin{array}{l}\text { Judgements } \\
(\times 1)^{\mathrm{c}}\end{array}$ & $\%$ success & $\begin{array}{l}\text { Judgements } \\
(\times 1)^{\mathrm{c}}\end{array}$ & $\%$ success \\
\hline \multicolumn{11}{|c|}{ Species or group of species } \\
\hline Carapa & 5 & 34 & 97 & $100(16)$ & 0 & - & 8 & 100 & 2 & 100 \\
\hline Gonfolo rose & 18 & 96 & 94 & $96(46)$ & 8 & 87.5 & 40 & 85 & 11 & 82 \\
\hline Gonfolo gris & 6 & 8 & 88 & $100(5)$ & 0 & - & 0 & - & 1 & 0 \\
\hline Lebi koko & 7 & 37 & 87 & $90(19)$ & 0 & - & 0 & - & 0 & - \\
\hline Angélique & 7 & 6 & 83 & $100(1)$ & 1 & 0 & 5 & 60 & 2 & 50 \\
\hline Wacapou & 10 & 23 & 83 & $83(12)$ & 0 & - & 0 & - & 0 & - \\
\hline Diaguidia & 12 & 15 & 80 & $100(5)$ & 2 & 0 & 2 & 0 & 0 & - \\
\hline Grignon & 6 & 10 & 80 & $100(1)$ & 0 & - & 0 & - & 2 & 0 \\
\hline Symphonia & 8 & 17 & 77 & $88(8)$ & 2 & 50 & 8 & 75 & 2 & 100 \\
\hline Maho cigare & 7 & 4 & 75 & $100(2)$ & 0 & - & 3 & 0 & 0 & - \\
\hline Kimboto & 10 & 11 & 73 & $80(5)$ & 1 & 100 & 3 & 100 & 0 & - \\
\hline Goupi & 5 & 7 & 43 & $60(5)$ & 1 & 100 & 3 & 33 & 0 & - \\
\hline Total & 101 & 268 & 87 & 94 & 13 & 67 & 72 & 76 & 20 & 70 \\
\hline
\end{tabular}

SGS are ordered by decreasing average \% success on VS 1.

a Scale.

b Separate judgements.

c Joint judgements.

identifications on VS 1. In order to make things clearer, only definite identifications, which carry the most weight in the interpretation of the results, are presented hereafter. However, information from hesitant identifications is not neglected and will be considered in the discussion. It can already be specified that adding the hesitant identifications on VS1 has only improved the success rate for the three least well definitely-recognized SGS (average percent success $\leq 75 \%$ : Goupi, Kimboto and Maho cigare). Results of identification on VS 2 are given for the three photographic scales available. Since the photo-interpreters worked jointly for this test and the stand area is smaller ( $6.25 \mathrm{ha}$ instead of $10 \mathrm{ha})$, this explains the lesser number of judgements encountered. Moreover, an important shadow effect on the photo at 1:8000 made any identification impossible on about half the stand at this scale.

3.2.3.1. Validation set 1: conditions similar to training. The overall success rate of $87 \%$ masks a considerable disparity according to the SGS. Average success rate varies from $43 \%$ for Goupi to $97 \%$ for Carapa, and the number of correct identifications varies from three (Goupi, Maho cigare) to 90 (Gonfolo rose). The number of reference crowns used for the standard description is also very variable, ranging from five (Goupi, Carapa) to 18 for Gonfolo rose, the dominant species in the canopy. It seems that there is more chance for the photointerpreter to get better practice and thus better success at identifying the more dominant species. However, a small training set of five individuals can either be associated with low success in recognition (Goupi) or with good results (Carapa) depending on the intra-species variability.

\subsubsection{Validation set 2: conditions different from training.}

Only one species, Gonfolo rose, was identified with a high success $(>80 \%)$ at any scale, based on frequent observations (from 8 trees at 1:1500 to 40 trees at 1:3000). Carapa and Symphonia were correctly identified, respectively, eight and six times each at the scale of 1:3000, with a success of 100 and $75 \%$, and these species were also correctly identified twice at the scale of 1:8 000 (100\% success). Three Kimboto and three Angélique were correctly identified at 1:3000 (100 and $60 \%$ success, respectively), but at the other scales for

Table 5

Details of the most significant cases of confusion between two SGS (species or group of species) including, at least, one definite identification

\begin{tabular}{ll}
\hline $\begin{array}{l}\text { Identification by } \\
\text { photo-interpretation }\end{array}$ & Ground truth (Paracou database) \\
\hline $\begin{array}{l}\text { Unique confusion (one photo-interpreter) } \\
\text { Diaguidia }\end{array}$ & Grignon \\
Diaguidia & Gonfolo rose \\
Gonfolo gris & Angélique \\
Grignon & Baaka apici (Ocotea sp., Lauraceae) \\
Grignon & Niamboka (Pouteria guianensis, Sapotaceae) \\
Kimboto & Maho cigare \\
Symphonia & Weti pediekou (Xylopia sp. 2, Annonaceae) \\
Symphonia & Tosso passa (Iryanthera spp., Myristicaceae) \\
Carapa & Singabassou (Talisia spp., Sapindaceae) \\
Joint confusion (both photo-interpreters) \\
Diaguidia & Maho cigare \\
Gonfolo rose & Baaka mapa (Couma guianensis, Apocynaceae) \\
Kimboto & Grignon \\
Symphonia & Kimboto \\
\hline
\end{tabular}

VS 1 (P16 plot, Paracou). 
these species, and at any scales for any other species, the number of correct identification is very low, from 0 to 1 . Six among the 12 sought-after SGS were never recognised on this stand: Lebi koko, Wacapou, Diaguidia, Grignon, Gonfolo gris, Maho cigare. Generally, the best identification successes were obtained at the scale of 1:3000 (76\% in average), for a higher number of judgements (72). The success reaches $70 \%$ in average at the scale 1:8000, despite the impossibility to exploit half of the area covered (only 20 judgements). The lowest results were obtained at the scale of 1:1500, with $67 \%$ success for 15 judgements only.

\subsubsection{Confusion between species or group of species}

The interpretation errors allow for interesting similarities between SGS to be highlighted. Most cases of confusion concerned hesitant judgements and only one of the two photointerpreters, and therefore have little significance and will not be discussed in detail. No confusion of a given SGS has occurred more than once, which suggests they might be the result of atypical trees rather than of a general resemblance between two SGS. Out of 309 observations in VS 1, only five cases of unique confusion (by one interpreter) for definite identification, and five cases of double confusion (both interpreters) with at least one definite identification, are noted. Details of these most significant cases of confusion are shown in Table 5.

\section{Discussion}

The percentages of successful identifications must first be analysed in relation to the number of judgements on which they were established. The higher this number, the more reliable the identification success will be. Likewise, the better the agreement between the two photo-interpreters over SGS identification, the easier this SGS will be to identify, the more adequate its standard description will be, and the more reproducible the identification from one person to another. Finally, the degree of certainty with which the SGS is recognized is also important for the analysis. The more often a SGS is definitely recognized, the more constant it will be in relation to the reference criteria. When recognized with hesitation, the initially proposed standard description will need broadening to cover a greater variation. Taking these considerations into account, we discuss the identification success of each SGS and the ease of their identification by photo-interpretation, in case of conditions similar to training and different from training.

\subsection{Identification success under conditions similar to training}

\subsubsection{Gonfolo rose, Carapa, Lebi Koko, Wacapou (nine or more correct and definite identifications by each photo- interpreter)}

These SGS were correctly identified on numerous occasions, almost always definitely, and often by both interpreters. Confusion over these SGS is rare, their success rates are over
$80 \%$ ( $94 \%$ for Gonfolo rose): they are the easiest to identify. A joint confusion over a Singabassou (Talisia spp., Table 5) identified as a Carapa can be explained by an architectural analogy. Indeed, some Talisia species (Sapindaceae family) have large componed leaves inserted on an orthotropic axis, that may induce a star-shaped crown.

\subsubsection{Diaguidia, Symphonia (five or more correct and definite identifications by each photo-interpreter)}

Diaguidia had been definitely recognized seven and five times respectively by each photo-interpreter with $100 \%$ success in the latter case. Hence, this species remains classified as easily identifiable.

Symphonia was often correctly definitely recognized by both interpreters. Since Symphonia was the only SGS to possess a star-shaped crown among the 78 SGS observed in the reference set, one interpreter was confident in her judgement and made confusions with other SGS displaying a star-shaped crown (Xylopia sp.2, Iryanthera spp., Table 5), even when differences were noticeable among other criteria. This SGS therefore remains classified as easy to identify.

\subsubsection{Gonfolo gris, Grignon (five or more correct and definite identifications by only one photo-interpreter)}

All the judgments concerning Gonfolo gris (Ruizterania albiflora) were definite ones. Since this species is quite scarce on the photograph area (six reference crowns only on the 5 ha training set), a larger number of observations would confirm the ability to identify it.

The variability of Grignon crowns limited the definite judgements for one of the photo-interpreters. We can note a case of confusion with Ocotea sp., another Lauraceae species, but also with a Diaguidia and a Kimboto (Table 5), two species with very different characteristics. The irregular nature of the crown of Grignon described in reference on a limited number of individuals (six trees) seems to apply to old trees, whereas young trees have a rounder crown with a regular contour.

\subsubsection{Kimboto, Angélique, Maho cigare, Goupi (less than five correct and definite identifications by each photo- interpreter)}

Four crowns of Kimboto, true to the reference specimens, were definitely recognized by both photo-interpreters. Four other crowns were identified with hesitation by one photointerpreter only. Taking hesitant judgements into account increases the mean success rate from 72.7 to $80 \%$. The spectrum of definition of the standard crown will therefore need to be widened in accordance with these new observations.

Few Angélique individuals were definitely recognized despite high percent of success. The low number of identifications does not enable us to reach a conclusion about the efficacy of its aerial reconnaissance.

The success rate of Maho cigare amounts to $80 \%$, including hesitant judgements. Only three correct definite identifications were made, five others with hesitation. This tree category is therefore more variable than assumed. For that matter it has been mistaken for other species: Kimboto, Diaguidia (Table 5). 
The Maho cigare designation used by prospectors encompasses several species and a botanical identification of each tree would be necessary in that case.

Goupi posed many confusion problems, and caused hesitation. The recognized individuals did not meet all the proposed identification criteria. Adding the hesitant judgements raised the success rate from 42.9 to $54.5 \%$. Completion of this species description must therefore be considered on the basis of other observations, and eventually using the location of this long-lived pioneer on the edges of old middle-size gaps (Oldeman and Van Dijk, 1991).

\subsection{Identification success under conditions different from training: the effects of scale and phenological variations}

The test of identification success in conditions different from training is limited by the fact that some of the sought-after SGS appeared to be rare on VS 2, only a few hundred meters distant from TS and VS 1. When looking in the database for the abundance of SGS above $20 \mathrm{~cm}$ of dbh on VS 2, Lebi koko, Wacapou, Diaguidia, Grignon, Gonfolo gris, which were never recognized on this site by the photo-interpreters, are poorly represented over this diameter limit $(<10$ individuals over the $6.25 \mathrm{ha}$ ). Their ability to spread-out their crown in the canopy is very low and we therefore cannot discuss their identification in more details. On the contrary, the other SGS are abundant over this diameter threshold.

\subsubsection{Gonfolo rose, Carapa and Symphonia: no variations through scales and seasons}

The crown criteria used for the identification of Gonfolo rose, Carapa and Symphonia remains usefull in these new conditions, as the results are also good compared to those obtained on VS 1. These species were not subjected to morphological changes between the two sites and the two main seasons, and remain identifiable at various scales, up to 1:8000.

\subsubsection{Angélique and Kimboto: phenological variations}

Results obtained for Angélique and Kimboto lead to other conclusions. These species are as abundant or more on VS 2 (29 individuals of Angélique and 49 Kimboto) than on double the area on P16 over the $20 \mathrm{~cm}$ dbh threshold, but we only identified three of them at the best. This result was not surprising regarding the intra-species phenological variability of Angélique previously observed in French Guiana (Loubry, 1994). Various degrees of foliation or fructification of the individuals probably hampered their recognition on VS 1 , and the problem was exacerbated on VS 2 given the abundance of the species (Photo 3). Concerning Kimboto, the result highlights the phenological change of this species between seasons. Indeed, subsequent direct observations lead us to conclude that during the dry season many Kimboto in the canopy progressively turn their foliage from green to yelloworange, before loosing totally their leaves for a few days. Then, the foliage comes again with a green colour that persists during the rainy season, and this behaviour seems to be synchronous among most individuals. The photographs on TS and VS 1

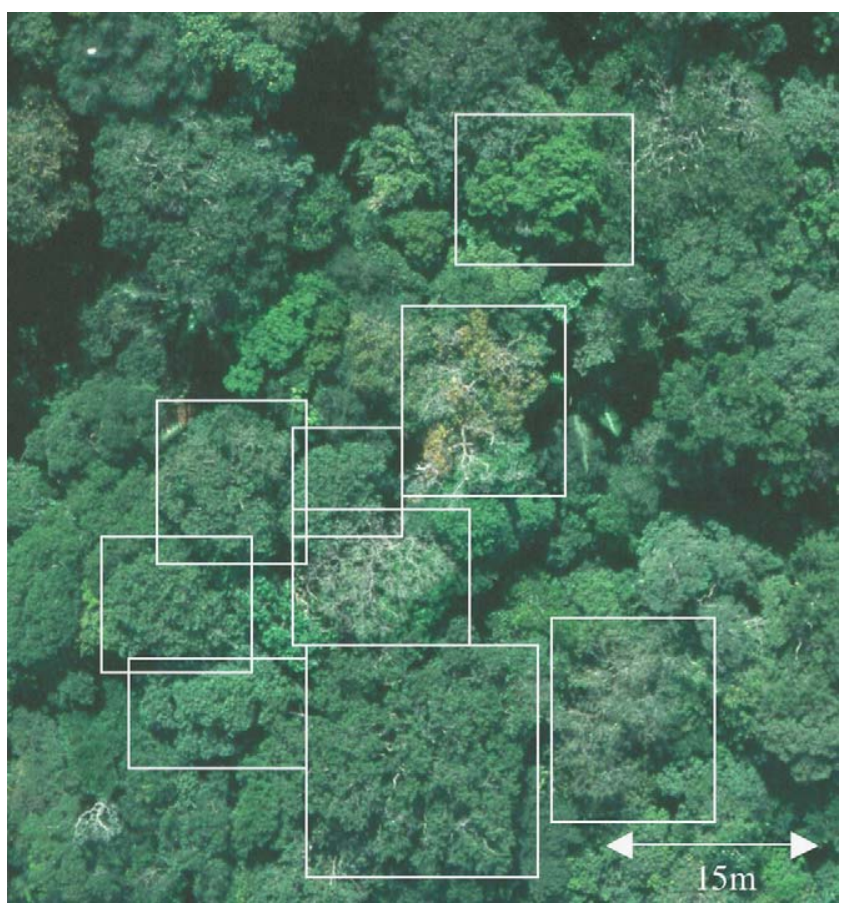

Photo 3. A clumping of Angélique trees (Dicorynia guianensis) displaying various phenological status and crown features (colour, foliage cover and texture). P11 plot, Paracou. Photograph, D. Guillemyn.

captured the period of yellow-orange colour, whereas most of the individuals displayed a green colour on VS 2, hampering the identification of the species. We are aware that many factors may induce colour variations between two photographic campaigns (here, environmental light or development process). Even if the photographs over VS 2 are generally darker than over TS and VS 1, it did not hamper the recognition of some yellow crowns of Kimboto on VS 2 (Photo 4).

\subsubsection{The largest scale (1:1500): better for complementary information}

Two factors may explain the very low success and judgement numbers performed at the scale of 1:1500 compared to the two other scales. First, at this very large scale, big tree crowns are often only partially visible on each photograph. Only a photo-mosaic would restore the totality of the crown as well as the "canopy context" around, which is necessary to attribute the criteria of crown status (dominant, co-dominant, or suppressed, Table 1). Second, the small crowns (Symphonia, Carapa) with a status of co-dominant or suppressed, may also be disadvantaged by a higher parallax effect at this larger scale and by a highest shadow effect due to an earlier time of flight $(9.30 \mathrm{am})$. Thus, even if this very large scale brings interesting details including foliage and architectural components of the crowns (Photo 1), it would be better used as a source of complementary information for tree identification.

\subsection{From identification success to identification rate}

The identification success as defined by Myers and Benson (1981), does not consider the number of crowns potentially 

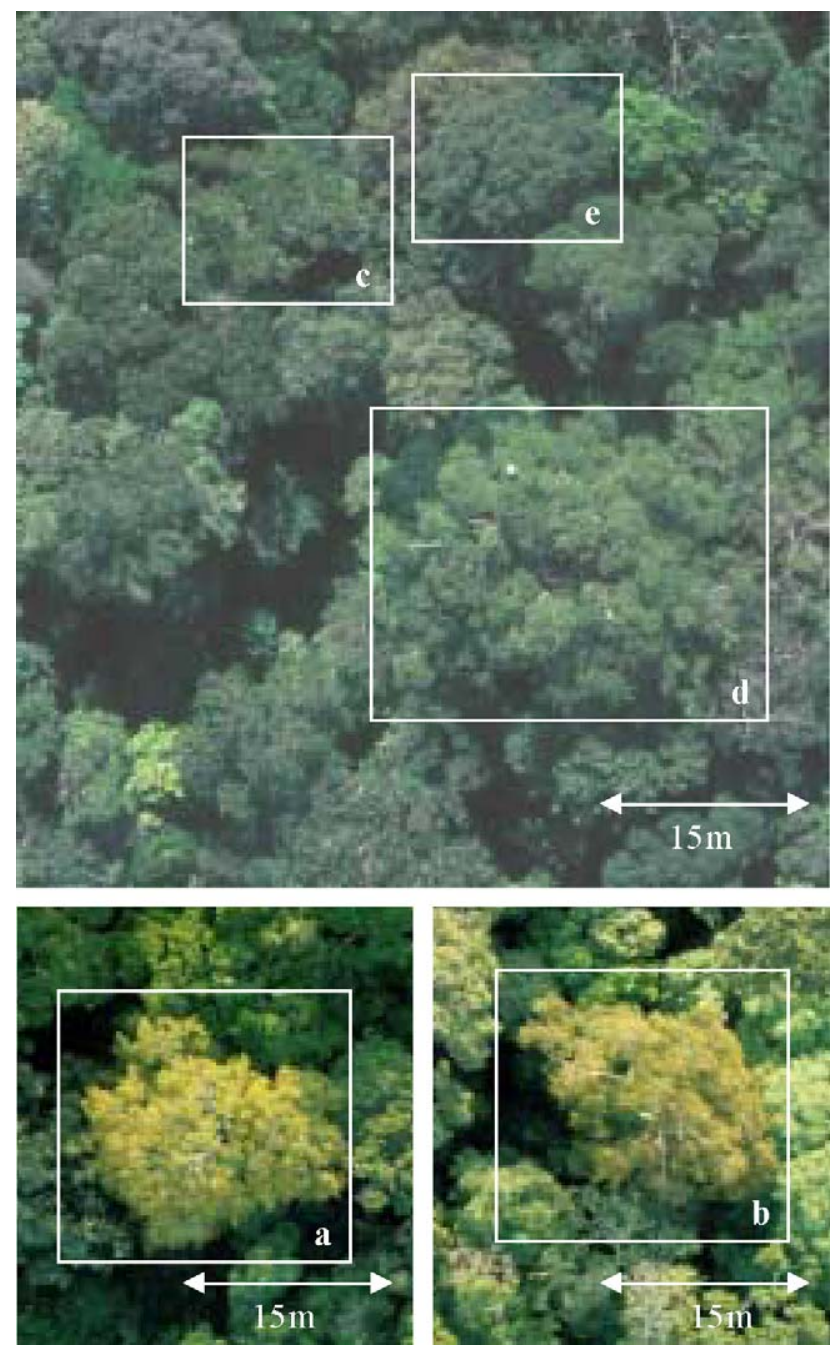

Photo 4. Kimboto crowns (Pradosia cochlearia) at Paracou, displaying yellow colours in october (P16 plot, a and b); yellowgreen colour in july (P11 plot, c), or green colour in july (P11 plot, d and e). Photographs, D. Guillemyn.

visible on the photographs but not recognized by the photointerpreters. This could be considered in the "identification rate", that we define as the number of good identifications over the number of crowns visible on the photographs. This information could be useful if an exhaustive identification of one particular species would be required. During field checks, some cases of confusion that arose among the 12 SGS studied highlighted some of the potential omissions. Thus, 2 Grignon, 2 Maho cigare, 1 Gonfolo rose, 1 Angélique and 1 Kimboto were not identified as such (Table 5). It can therefore not be excluded that some SGS may in fact be more variable than suggested by the current results. As we saw before, an intra-specific variability of the phenological rhythm limits the identification of all the individuals of a species at a given time. Therefore, a greater knowledge of the phenological rhythms of the species would be useful. Moreover, as underlined by Myers and Benson (1981), other ecological knowledge of the species, such as preference for specific light or topographic conditions, when known, should be added to crown description criteria to improve both the identification success and identification rate. On VS 2 , a prolonged field trip allowed to calculate an identification rate of over 50\% for Carapa, Gonfolo rose and Symphonia.

\section{Conclusion}

Aerial photographs captured about a quarter of the community of trees $(\mathrm{dbh} \geq 10 \mathrm{~cm})$ on average, a result comparable to that obtained by Herwitz et al. (1998) (28\% over $0.5 \mathrm{ha}$ ), and at least $45 \%$ of the SGS on 4 ha forest area (Table 3). This portion of the cover excludes trees under $20 \mathrm{~cm}$ dbh, a threshold commonly admitted in previous works (Aldred, 1976). Thus, tree species of small size, whatever their characteristics, cannot be investigated through this method. Contrarily, the approach works well for tall tree species. Among them, rare species will be difficult to catch because of the difficulty to get training samples and because their chance to appear in large areas of survey will be low. More abundant species are better suited to this method as long as the intra-species variability is not too great. The more the crowns display original visual characteristics, the easier they will be for identification.

During the description phase of this study based on the more abundant SGS of TS, all of them initially appeared identifiable with a reservation regarding Angélique (Trichon, 2001). At the conclusion of the photo-interpretation results, seven of these SGS actually remain classified as easily identifiable in conditions similar to training (Gonfolo rose, Carapa, Lebi koko, Wacapou, Symphonia, Diaguidia and Gonfolo gris). Two other species are identifiable with good results that will be improved by broadening the standard description (Grignon and Kimboto), whereas the results for Angélique, Maho cigare and Goupi elicit caution. An extension of our training set to other Guianese forest sites will enable us to enlarge the list of studied species. Two other interesting species already appear identifiable through the analysis of VS 1 and VS 2: Laetia procera (Kaïman oudou), a long-lived pioneer such as Goupi, and Platonia insignis (Parcouri), a sun-loving species like Diaguidia. Three SGS remain identifiable when we change site, scale and season (Gonfolo rose, Carapa, Symphonia). Managing to distinguish among species according to criteria that are not very sensitive to scale or phenological variation may allow for more flexibility in their use for a given learning effort.

This study utilizing large-scale aerial photographs provides a significant contribution to analysis of very high-resolution (VHR) remote sensing data. New generation of VHR satellite data such as IKONOS or Quickbird do not yet bring a sufficient spatial resolution to enable species identifications. However, they may complete aerial photograph data sets as soon as we are able to link the scales. As a consequence, an automation of our interpretation procedure is presently under investigation. Automatic delineation of individual crowns has been attempted in homogeneous tree stands (Gougeon, 1995; Pouilot et al., 2004) but rarely in heterogeneous tropical forest. We develop a segmentation method based on colour, texture and shape criteria, and work within an image processing environment that automatically designs recognition operators at several spatial resolutions (Dalle and Abchiche, 2001). 
This study has shown that the identification of certain Guianese tree species (or group of species) by photointerpretation produced useful results. These species are either commercial species, or medicinal resource for indigenous people, or provide food for animals, or give an indication about local past disturbances as long-lived pioneer species. It is easily conceivable to apply this method of species identification for forest survey, especially in remote locations. It may be used to assess the commercial or conservation value of a forest, based on the recognition of appropriate species such as commercial species and patrimonial or endemic species. An aerial perspective of the canopy may be useful as well to formulate decisions in regard to sustainable forest management. For example, it may be useful to design trails of access to avoid damaging important species during logging. Selecting the noncommercial trees that should be suppressed to favour the growth of interesting species may also be facilitated by the view of crowns overlap. It is therefore our mandate that it is important to continue developing this area of research that has multiple applications, ranging from fundamental ecological knowledge of canopy species to the management and conservation of complex ecosystems that are tropical rainforests.

\section{Acknowledgments}

This work was carried out as part of a project research supported by the Silvolab Scientific committee in French Guiana. The authors thank the CIRAD-forêt for access to Paracou site and to Paracou database, and all the ECOFOG staff in Kourou for their warm welcome and logistical help in the field. Daniel Guillemyn as the photographer and Dany CleyetMarrel as the pilot did a very good job during the "Opération Guyane 96" mission that allowed us to start this work with such a good photographic data set. Several students are warmly thanked for their energetic help in the field: Claire Couly, Frederic Delsanti, Sandrine Galletti, Julie Meudec, Jean Olivier and Isabelle Sendrané. Sincere acknowledgments are directed to two reviewers who helped improving the paper and to Pr. Steven Turton for providing final feedback on the manuscript.

\section{References}

Aldred, A.H., 1976. Measurement of tropical trees on large-scale aerial photographs. Information Report FMR-X-86. Forest Management Institute, Ottawa, Ontario.

Anonymous, 2001. Guide de reconnaissance des arbres de Guyane. Office National des Forêts, Direction régionale de Guyane, Cayenne.

Boggan, J., Funk, V., Kelloff, C., Hoff, M., Cremers, G., Feuillet, C., 1997. Checklist of the Plants of the Guianas (Guyana, Surinam, French Guiana), second ed. Smithsonian Institution, Washington, DC.

Chareyre P., 1998. Etude de la structure tridimensionnelle de la canopée. Possibilités d'application de l'imagerie aérienne à basse altitude en milieu forestier tropical. Rapport final Silvolab Guyane.

Clark, D.B., Read, J.M., Clark, M.L., Cruz, A.M., Dotti, M.F., Clark, D.A., 2004. Application of 1-m and 4-m resolution satellite data to ecological studies of tropical rain forests. Ecol. Appl. 14, 61-74.

Clément, J., Guellec, J., 1974. Utilisation des photographies aériennes au 1:5000 en couleur pour la détection de l'Okoumé dans la forêt dense du Gabon. Bois et Forêts des Tropiques 153, 3-22.
Dalle P., Abchiche Y., 2001. Agents de médiation pour la conception de systèmes de traitement d'images. In: Agents Logiciels, Coopération, Apprentissage et Activité humaine-ALCAA, Biarritz, pp. 8-20.

Détienne, P., Fouquet, D., Parant, B., 1990. Les bois guyanais. Propriétés et utilisation. Bois et Forêts des Tropiques 219, 125-143.

Gentry, A.H., 1992. Tropical forest biodiversity: distributional patterns and their conservational significance. Oikos 63, 19-28.

Gougeon, F.A., 1995. A crown-following approach to the automatic delineation of individual tree crowns in high spatial resolution aerial images. Can. J. Rem. Sens. 21, 274-284.

Gourlet-Fleury, S., Ferry, B., Molino, J.-F., Petronelli, P., Schmitt, L., 2004. Experimental plots: key features. In: Gourlet-Fleury, S., Guehl, J.-M., Laroussinie, O. (Eds.), Ecology and management of a neotropical rainforest: lessons drawn from Paracou, a long-term experimental research site in French Guiana. Elsevier, pp. 3-52.

Grenand, P., Moretti, C., Jacquemin, H., 1987. Pharmacopées traditionnelles en Guyane. Créoles, Palikur, Wayapi. ORSTOM, Paris, France.

Herwitz, S., Slye, R., Turton, S., 1998. Redefining the ecological niche of a tropical rain forest canopy tree species using airborne imagery: long-term crown dynamics of Toona ciliata. J. Trop. Ecol. 14, 683-703.

Hill, J., 2003. Area, shape and isolation of tropical forest fragments: effects on tree species diversity and implication for conservation. J. Biogeogr. 30, $1391-1403$.

Hobhom, C., 2003. Characterization and ranking of biodiversity hotspots: centres of species richness and endemism. Biodivers. Conserv. 12, 279-287.

Loubry, 1994. Déterminisme du comportement phénologique des arbres en forêt tropicale humide de Guyane française. Thèse de Doctorat, Bio. Veg. Trop., Univ. Paris 6.

Margules, C.R., 2000. Systematic conservation planning. Nature 405, 243-253.

Mittermeier, R.A., Myers, N., Thomsen, J.B., da Fonseca, G.A.B., Olivieri, S., 1998. Biodiversity hotspots and major tropical wilderness area: approaches to setting conservation priorities. Conserv. Biol. 12, 516-520.

Myers, B.J., 1982. Guide to the identification of some tropical rainforest species from large-scale colour aerial photographs. Aust. Forester 45 (1), 28-41.

Myers, B.J., Benson, M.L., 1981. Rainforest species on large-scale colour photos. Photogramm. Eng. Remote Sensing 41, 505-513.

Myers, N., Mittermeier, R.A., Mittermeier, C.G., da Fonseca, G.A.B., Kent, J., 2000. Biodiversity hotspots for conservation priorities. Nature 403, $853-$ 858.

Nyyssönen, A., 1962. Aerial photographs in tropical forests. Unasylva 16, 3-12.

Oldeman, R.A.A., Van Dijk, J., 1991. Diagnosis of the temperament of tropical rain forest trees. In: Gomez-Pompa, A., Whitmore, T.C., Hadley, M. (Eds.), Rain forest regeneration and management. Man and the Biosphere series 6. Unesco \& the Parthenon Publishing group, Paris, pp. 21-65.

Pouilot, D.A., King, D.J., Bell, F.W., Pitt, D.G., 2004. Automated tree crown detection and delineation in high resolution digital camera imagery of coniferous forest regeneration. Remote Sens. Environ. 82, 322-334.

Read, J.M., Clark, D.B., Venticinque, E.M., Moreiras, M.P., 2003. Application of merged 1-m and 4-m resolution satellite data to research and management in tropical forests. J. Appl. Ecol. 40, 592-600.

Sabatier, D., Prévost, M.-F., 1990. Quelques données sur la composition floristique et la diversité des peuplements forestiers de Guyane française. Bois et Forêts des Tropiques 219, 31-55.

Sayn-Wittgenstein, L., De Milde, R., Inglis, C.J., 1978. Identification of tropical trees on aerial photographs. For. Manage. Inst., Canada Inf. Re FMR-X-113.

Sutton, S.L., 2001. Alice grows up: canopy science in transition from Wonderland to Reality. Plant Ecol. 153, 13-21.

Trichon, V., 2001. Crown typology and the identification of rain forest trees on large-scale aerial photographs. Plant Ecol. 153, 301-312.

Trichon, V., Guillemyn, D., Fromard, F., 1998. Cartographie d'une canopée de forêt tropicale par photographies aériennes numériques et analogiques. In: Hallé, F. (Ed.), Biologie d'une canopée de forêt équatoriale III. Pro-Natura International \& Opération Canopée, Paris, pp. 26-36.

Vooren, A.P., Offermans, D.M.J., 1985. An ultra-light aircraft for low-cost, large-scale stereoscopic aerial photographs. Biotropica 17 (1), 84-88. 